\title{
An overview of the potential anticancer properties of cardamonin
}

\author{
Shanaya Ramchandani ${ }^{1}, \operatorname{Irum~Naz}^{2}$, Namrata Dhudha ${ }^{3}$, Manoj Garg $^{4}{ }^{*}$ (i) \\ ${ }^{1}$ Department of Pharmacology Biomedicine, the University of Melbourne, Parkville Victoria 3010, Australia \\ ${ }^{2}$ Department of Biochemistry, Quaid-i-Azam University, Higher Education Commission of Pakistan, Islamabad 44000, Pakistan \\ ${ }^{3}$ Department of Biotechnology and Microbiology, School of Sciences, Noida International University, Noida 201301, India \\ ${ }^{4}$ Amity Institute of Molecular Medicine and Stem cell Research (AIMMSCR), Amity University Uttar Pradesh, Noida 201313, India
}

*Correspondence: Manoj Garg, Amity Institute of Molecular Medicine and Stem cell Research (AIMMSCR), Amity University Uttar Pradesh, Noida 201313, India. mgarg@amity.edu; nuscsimg@gmail.com

Academic Editor: Gautam Sethi, National University of Singapore, Singapore

Received: July 30, 2020 Accepted: November 26, 2020 Published: December 28, 2020

Cite this article: Ramchandani S, Naz I, Dhudha N, Garg M. An overview of the potential anticancer properties of cardamonin. Explor Target Antitumor Ther. 2020;1:413-26. https://doi.org/10.37349/etat.2020.00026

\begin{abstract}
Cancer is one of the leading causes of mortality, contributing to 9.6 million deaths globally in 2018 alone. Although several cancer treatments exist, they are often associated with severe side effects and high toxicities, leaving room for significant advancements to be made in the field. In recent years, several phytochemicals from plants and natural bioresources have been extracted and tested against various human malignancies using both in vitro and in vivo preclinical model systems. Cardamonin, a chalcone extracted from the Alpinia species, is an example of a natural therapeutic agent that has anti-cancer and anti-inflammatory effects against human cancer cell lines, including breast, lung, colon, and gastric, in both in vitro culture systems as well as xenograft mouse models. Earlier, cardamonin was used as a natural medicine against stomach related issues, diarrhea, insulin resistance, nephroprotection against cisplatin treatment, vasorelaxant and antinociceptive. The compound is well-known to inhibit proliferation, migration, invasion, and induce apoptosis, through the involvement of Wnt/ $\beta$-catenin, NF- $\mathrm{BB}$, and PI3K/Akt pathways. The good biosafety and pharmacokinetic profiling of cardamonin satisfy it as an attractive molecule for the development of an anticancer agent. The present review has summarized the chemo-preventive ability of cardamonin as an anticancer agent against numerous human malignancies.
\end{abstract}

\section{Keywords}

Cancer, cardamonin, chalcone, apoptosis, proliferation, Wnt/ $\beta$-catenin, NF- $\kappa \mathrm{B}, \mathrm{PI} 3 \mathrm{~K} / \mathrm{Akt}$

\section{Introduction}

Cancer is the second-leading cause of death worldwide, following cardiovascular disease, and accounts for 1 in every 6 deaths [1-6]. According to the National Cancer Institute, there is nearly a $40 \%$ chance of men and women developing cancer at some point during their lifetime $[1,2]$. The most common cancers include breast, lung, liver, ovarian, colorectal, and prostate [1-6]. Several chemotherapeutic treatments exist for these malignancies. However, these treatments are not effective in generating long-term remission and improved

(C) The Author(s) 2020. This is an Open Access article licensed under a Creative Commons Attribution 4.0 International License (https://creativecommons.org/licenses/by/4.0/), which permits unrestricted use, sharing, adaptation, distribution and reproduction in any medium or format, for any purpose, even commercially, as long as you give appropriate credit to the original author(s) and the source, provide a link to the Creative Commons license, and indicate if changes were made. 
quality of life [1-6]. The majority of cancer deaths occur in lower-income families, due to the high cost of treatment options in clinics [1-6]. Therefore, substantial effort has been explored to find out alternative, cost-effective, less toxic treatments that are widely available. The products comprising these options can be derived from natural resources and their compounds [7-11].

Cancer is a disease characterized by abnormal and uncontrolled cellular proliferation, forming malignant tumors that can spread or metastasize to other parts of the body [8,12]. Cancer cells can grow rapidly, invade, and migrate through the lymphatic and circulatory systems $[8,12]$. Hanahan and Weinberg have proposed several hallmarks of cancer such as proliferative advantage, the ability to invade, the ability to migrate from the primary site, metastasis, selective growth, altered stress responses, and immune modulation [12]. Several risk factors promote these hallmarks, including smoking, obesity, alcohol, aging, genetic dispositions, exposure to UV radiation, chemicals, and some viral infections, such as human papillomavirus and hepatitis B virus. These risk factors have either individual roles or can work in conjunction with one another to promote the growth and proliferation of cancer cells [7, 12]. Numerous cancer treatments, such as radiation and chemotherapy, have been put into place. However, these are often associated with detrimental side effects, such as erosion of the digestive lining, loss of test buds, liver toxicity, renal injury as well as hair loss. Most of the existing anticancer drugs have lower specificity and selectivity towards cancer cells. Hence, they affect normal living cells. Additionally, many of these drugs are also toxic, which leads to high mortality rates [13-14].

As a result, several natural compounds have been tested against cancer cell lines in preclinical and clinical phases, including herbs, spices, pulses, and nuts. In fact, several successful anticancer drugs such as docetaxel, paclitaxel, topotecan have been isolated from plants and herbs. These bioresources are rich sources of phytochemical agents that have been displayed to possess therapeutic properties against human cancer cell lines. For example, natural drugs such as casticin, extracted from the Fructus viticus species have been used as an analgesic for menstrual pain in females. Also, casticin was reported with antineoplastic effects in cancer cell lines and mouse models [15]. Zerumbone, derived from Z. zerumbut, is known for its biochemical properties as well as antiproliferative activity against human malignancies drawing attention for further research by the scientific community [16].

Likewise, cardamonin, a naturally occurring chalcone isolated from several cardamom plants (specifically, Alpinia katsumadai and Alpinia conchigera), have been used as a treatment for numerous ailments in South America [17-18]. It is a component of the Myrtacae family that has been conventionally used to treat stomach issues and diarrhea. In recent years, significant emphasis has been placed on the role of cardamonin as an anticancer agent. Cardamonin mediates inflammation, targets pathogens, and modulates the immune system [19-20]. Numerous studies have been conducted on cardamonin role against lung, breast, prostate, and colon cancer, in vitro and in vivo. Interestingly, cardamonin has been shown to be effective against aggressive deadlier cancers including glioblastoma, multiple myeloma, melanoma, nasopharyngeal carcinomas (NPCs), and ovarian [17-28]. Also, reports have shown promising effects of the compound, particularly through the Wnt and nuclear factor kappa-light-chain enhancer (NF- $\kappa B$ ) pathways. This review details the potential anticancer activity of cardamonin along with molecular mechanisms of action in human cancers.

\section{Chemistry}

Cardamonin (CARD/CD) is chemically known as (E)-2',4'-dihydroxy-6'-methoxy-chalcone which is derived from a group of aromatic enones which belong to a family of flavonoids, contributing to the yellow-color of pigmented plants. Many plants, such as Alpinia katsumadai and Alpinia conchigera, contain flavonoids that are responsible for anti-proliferative and apoptotic mechanisms. Cardamonin is an isolated chalcone and the molecular formula is $\mathrm{C}_{16} \mathrm{H}_{14} \mathrm{O}_{4}$ (Figure 1). Analogues of cardamonin include 4,4'-dihydroxylchalcone (DHC) and 4,4'-dihydroxy-2'-methoxychalcone (DHMC), which were used as substituents in some of the studies [29]. Naturally, chalcones are found in the leaf, fruit, or root of numerous plant species. Also, several chalcones can be artificially synthesized in laboratories through the acid-base catalyzation of an aldehyde or ketone for preclinical studies [30]. The molecular structure of cardamonin is depicted in Figure 1. 


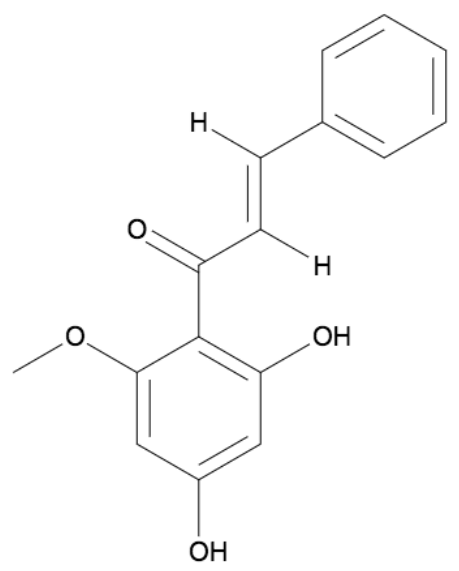

Figure 1. Molecular structure of cardamonin (ChemDraw)

\section{Anticancer effects of cardamonin in vitro cancer cell lines}

Cardamonin was reported to be effective in several human cancers including breast, cervical, colon, gastric, lung, ovarian, prostate, glioblastoma, leukemia, melanoma, and multiple myeloma. A summary of the effects of cardamonin on each of these malignancies is provided below, along with the half-maximal inhibitory concentrations ( $\mathrm{IC}_{50}$ values) for respective cell lines (Table 1 ). The primary mechanism for cardamonin is the mammalian target of rapamycin (mTOR) signaling pathway, which plays a crucial role in autophagy (the removal of damaged cells), inhibiting proliferation and regulating cell metabolism (Figure 2). Cardamonin can upregulate pro-apoptotic proteins such as Bcl-2 associated X protein (Bax) and caspase-3, and downregulate anti-apoptotic molecules such as B-cell lymphoma 2 (Bcl-2), thus inducing apoptosis in various cell lines (Figure 2).

Table 1. Anticancer effects of cardamonin in vitro

\begin{tabular}{|c|c|c|c|c|}
\hline Cancers & Cell line & Phenotypic effects & Mechanisms of action & References \\
\hline \multirow[t]{4}{*}{$\begin{array}{l}\text { Breast } \\
\text { cancer }\end{array}$} & $\begin{array}{l}\text { MDA-MB-231, } \\
\text { MCF-7 }\end{array}$ & $\begin{array}{l}\text { Induced apoptosis and G2/M cell } \\
\text { cycle arrest; inhibited proliferation }\end{array}$ & $\begin{array}{l}\uparrow R O S, \uparrow F O X O 3 a, \uparrow p 21, \uparrow p 27, \uparrow B i m, \\
\downarrow \text { Cyclin D1, } \uparrow \text { caspase-3 }\end{array}$ & [17] \\
\hline & BT-549 & $\begin{array}{l}\text { Induced apoptosis and cell cycle } \\
\text { arrest; decreased invasion and } \\
\text { migration }\end{array}$ & $\begin{array}{l}\uparrow E \text {-cadherin, } \downarrow \text { Snail, } \downarrow \text { Slug, } \downarrow \text { Vimentin, } \\
\uparrow G S K 3 B, \downarrow E M T, \downarrow \beta \text {-catenin }\end{array}$ & [20] \\
\hline & MDA-MB-231 & ROS-induced apoptosis & $\begin{array}{l}\downarrow \mathrm{HIF}-1 \mathrm{a}, \downarrow \mathrm{mTOR} / \mathrm{p} 70 \mathrm{SK}, \uparrow \mathrm{OXPHOS}, \\
\downarrow \text { Nrf2, } \uparrow \mathrm{ROS}\end{array}$ & {$[36]$} \\
\hline & $\begin{array}{l}\text { Drug-resistant } \\
\text { CSC's }\end{array}$ & $\begin{array}{l}\text { Suppresses existing cells and } \\
\text { prevents the formation of new cells }\end{array}$ & $\uparrow I L-6, \uparrow I L-8, \uparrow M C P-1$ & [37] \\
\hline $\begin{array}{l}\text { Cervical } \\
\text { cancer }\end{array}$ & HeLa & Inhibited cell proliferation & $\downarrow \mathrm{mTOR}, \downarrow \mathrm{S} 6 \mathrm{~K} 1, \downarrow$ raptor & [41] \\
\hline Colon cancer & HCT-116 & $\begin{array}{l}\text { Suppressed growth; induced } \\
\text { apoptosis }\end{array}$ & $\begin{array}{l}\uparrow \text { caspase- } 3, \uparrow \text { caspase- } 9, \uparrow \text { Bax, } \downarrow \text { c-Myc, } \\
\downarrow 4 \mathrm{k} \text { cyclin } \mathrm{E}, \downarrow \text { p50, } \downarrow \text { NF-kB p65, } \downarrow \text { Bcl-2 }\end{array}$ & {$[42,43]$} \\
\hline \multirow[t]{2}{*}{$\begin{array}{l}\text { Gastric } \\
\text { cancer }\end{array}$} & AGS & $\begin{array}{l}\text { Inhibited cell proliferation and } \\
\text { migration; induced apoptosis, cell } \\
\text { cycle arrest at G0/M phase }\end{array}$ & $\begin{array}{l}\uparrow \text { E-cadherin, } \downarrow \text { Snail, } \downarrow \text { Slug, } \downarrow \text { Vimentin, } \\
\downarrow \text { Bcl- } 2, \uparrow \text { Bax, } \downarrow \text { caspase- } 3, \downarrow \text { CDK1, } \downarrow \text { cyclin } \\
\text { B1, } \uparrow 21\end{array}$ & [49] \\
\hline & $\begin{array}{l}\text { BCG-823 and } \\
\text { BCG-823/5- } \\
\text { FU }\end{array}$ & $\begin{array}{l}\text { Enhanced chemosensitivity of } \\
5 \text {-FU; induced apoptosis, and cell } \\
\text { cycle arrest }\end{array}$ & $\begin{array}{l}\downarrow p \text {-glycoprotein, } \downarrow \beta \text {-catenin, } \downarrow \text { TCF-4, } \\
\downarrow \text { Wnt } / \beta \text {-catenin }\end{array}$ & {$[50]$} \\
\hline Glioblastoma & $\begin{array}{l}\text { CD133+ } \\
\text { GSCs }\end{array}$ & $\begin{array}{l}\text { Inhibited proliferation; induced } \\
\text { apoptosis }\end{array}$ & $\begin{array}{l}\downarrow \text { STAT3 }, \downarrow \mathrm{Bcl}-2, \downarrow \mathrm{Bcl}-\mathrm{L}, \downarrow \mathrm{Mcl}-1, \downarrow \text { Survivin, } \\
\downarrow \text { VEGF }\end{array}$ & {$[52]$} \\
\hline Leukemia & WEHI-3 & $\begin{array}{l}\text { Decreased cell viability; induced } \\
\text { apoptosis }\end{array}$ & $\begin{array}{l}\uparrow R O S, \uparrow \mathrm{Ca}^{2+}, \downarrow \Delta \Psi \mathrm{m}, \uparrow \text { caspase-3, } \\
\uparrow \text { caspase-8, } \uparrow \text { caspase-9, } \downarrow \text { Bcl- } 2, \uparrow \mathrm{Bax}, \\
\uparrow \text { cytochrome c, } \uparrow A I F, \uparrow \text { Endo G, } \uparrow \mathrm{GRP} 78, \\
\uparrow \text { caspase-12, } \uparrow \text { Fas, } \uparrow \text { Fas-ligand, } \uparrow F A D D, \\
\uparrow D A P, \uparrow T M B I B 4, \uparrow A T G 5, \downarrow D D I T 3, \downarrow D D I T 4, \\
\downarrow B A G 6, \downarrow B C L 2 L 13, \downarrow B R A T 1\end{array}$ & {$[53]$} \\
\hline
\end{tabular}


Table 1. Anticancer effects of cardamonin in vitro (Continue)

\begin{tabular}{|c|c|c|c|c|}
\hline Cancers & Cell line & Phenotypic effects & Mechanisms of action & References \\
\hline \multirow[t]{4}{*}{ Lung cancer } & $\begin{array}{l}\text { A549 and } \\
\mathrm{H} 460\end{array}$ & $\begin{array}{l}\text { Induced apoptosis, G2/M } \\
\text { cell cycle arrest; reduced cell } \\
\text { migration, and invasion }\end{array}$ & $\begin{array}{l}\uparrow \text { caspase-3, } \uparrow \text { Bax }, \downarrow \mathrm{Bcl}-2, \downarrow \text { cyclin D1, } \\
\downarrow \mathrm{CDK} 4, \downarrow \mathrm{PI} 3 \mathrm{~K}, \downarrow \mathrm{Akt}, \downarrow \mathrm{mTOR}\end{array}$ & {$[60]$} \\
\hline & LLC & $\begin{array}{l}\text { Reduced proliferation, invasion, } \\
\text { and migration }\end{array}$ & $\downarrow$ Snail, $\uparrow$ E-cadherin, $\downarrow$ mTOR, $\downarrow$ S6K1, $\downarrow$ NF-kB & [62] \\
\hline & $\begin{array}{l}\text { A549 and } \\
\mathrm{NCl}-\mathrm{H} 460\end{array}$ & Suppressed NF-kB activation & $\downarrow N F-k B$ & [63] \\
\hline & A549 & $\begin{array}{l}\text { Inhibited proliferation; induced } \\
\text { cell cycle arrest, and apoptosis }\end{array}$ & $\downarrow \mathrm{mTOR}, \downarrow$ p70S6K & {$[64]$} \\
\hline \multirow[t]{2}{*}{ Melanoma } & A375 & $\begin{array}{l}\text { Induced apoptosis and increased } \\
\text { cytotoxicity }\end{array}$ & $\uparrow$ caspase- $3, \uparrow$ PARP & {$[65]$} \\
\hline & M14 and A375 & $\begin{array}{l}\text { Inhibited cell viability and } \\
\text { migration; reduced cell density; } \\
\text { induced apoptosis }\end{array}$ & $\begin{array}{l}\downarrow \text { Bcl-2, } \uparrow \text { Bax, } \uparrow \text { cleaved caspase-8, } \uparrow \text { cleaved } \\
\text { caspase-9, } \uparrow \text { PARP, } \downarrow \text { NF-kB } p 65\end{array}$ & {$[61]$} \\
\hline \multirow[t]{2}{*}{$\begin{array}{l}\text { Multiple } \\
\text { myeloma }\end{array}$} & Myeloma cells & $\begin{array}{l}\text { Suppressed cell viability; induced } \\
\text { apoptosis }\end{array}$ & $\begin{array}{l}\uparrow \mathrm{PARP}, \downarrow \mathrm{Bcl}-2, \uparrow \mathrm{Bax}, \uparrow \text { caspase-3, } \downarrow \text { NF-kB, } \\
\downarrow \mathrm{IKK}, \downarrow \mathrm{IkBa}, \downarrow \text { ICAM- } 1, \downarrow \mathrm{COX}-2, \downarrow \text { VEGF }\end{array}$ & {$[70,71]$} \\
\hline & Myeloma cells & $\begin{array}{l}\text { Induced apoptosis and cell cycle } \\
\text { arrest; controlled proliferation }\end{array}$ & - & {$[70,71]$} \\
\hline \multirow[t]{2}{*}{$\begin{array}{l}\text { Ovarian } \\
\text { cancer }\end{array}$} & $\begin{array}{l}\text { SKOV3 and } \\
\text { A2780 }\end{array}$ & $\begin{array}{l}\text { Inhibited proliferation; induced } \\
\text { apoptosis }\end{array}$ & $\downarrow \mathrm{Bcl}-2, \downarrow \mathrm{XIAP}, \downarrow$ survivin, $\downarrow$ mTOR & [72] \\
\hline & SKOV3 & $\begin{array}{l}\text { Inhibited proliferation; enhanced } \\
\text { autophagy }\end{array}$ & $\begin{array}{l}\downarrow \text { Lactate }, \downarrow \text { ATP }, \downarrow \text { HK }, \downarrow \text { LDH }, \uparrow L C 3-I I, \\
\downarrow \text { mTORC } 1, \downarrow \text { H2K, } \uparrow \text { AMPK }\end{array}$ & [73] \\
\hline $\begin{array}{l}\text { Prostate } \\
\text { cancer }\end{array}$ & PC-3 & $\begin{array}{l}\text { Decreased cell proliferation, } \\
\text { growth, and viability; induced } \\
\text { apoptosis }\end{array}$ & $\downarrow$ STAT3, $\downarrow$ NF-kB1 & {$[74,75]$} \\
\hline
\end{tabular}

FOXO3a: Forkhead box O3; ROS: reactive oxygen species; HIF-1a: hypoxia-inducible factor-1a; Nrf2: NF-E2 related factor 2; OXPHOS: mitochondrial oxidative phosphorylation; CSC: cancer stem cell; STAT3: signal transducer and activator of transcription 3; IL-6: interleukin 6; IL-8: interleukin 8; EMT: epithelial-mesenchymal transition; GSC: glioblastoma stem cells; ATG5: autophagy-related 5; DDIT3: DNA-damage inducible transcript 3; LCC: Lewis lung carcinoma; S6K1: S56 kinase 1; PARP: poly(ADP-ribose) polymerase; LC3-II: light chain 3-II; Akt: protein kinase B; VEGF: vascular endothelial growth factor; XIAP: X-linked inhibitor of apoptosis protein

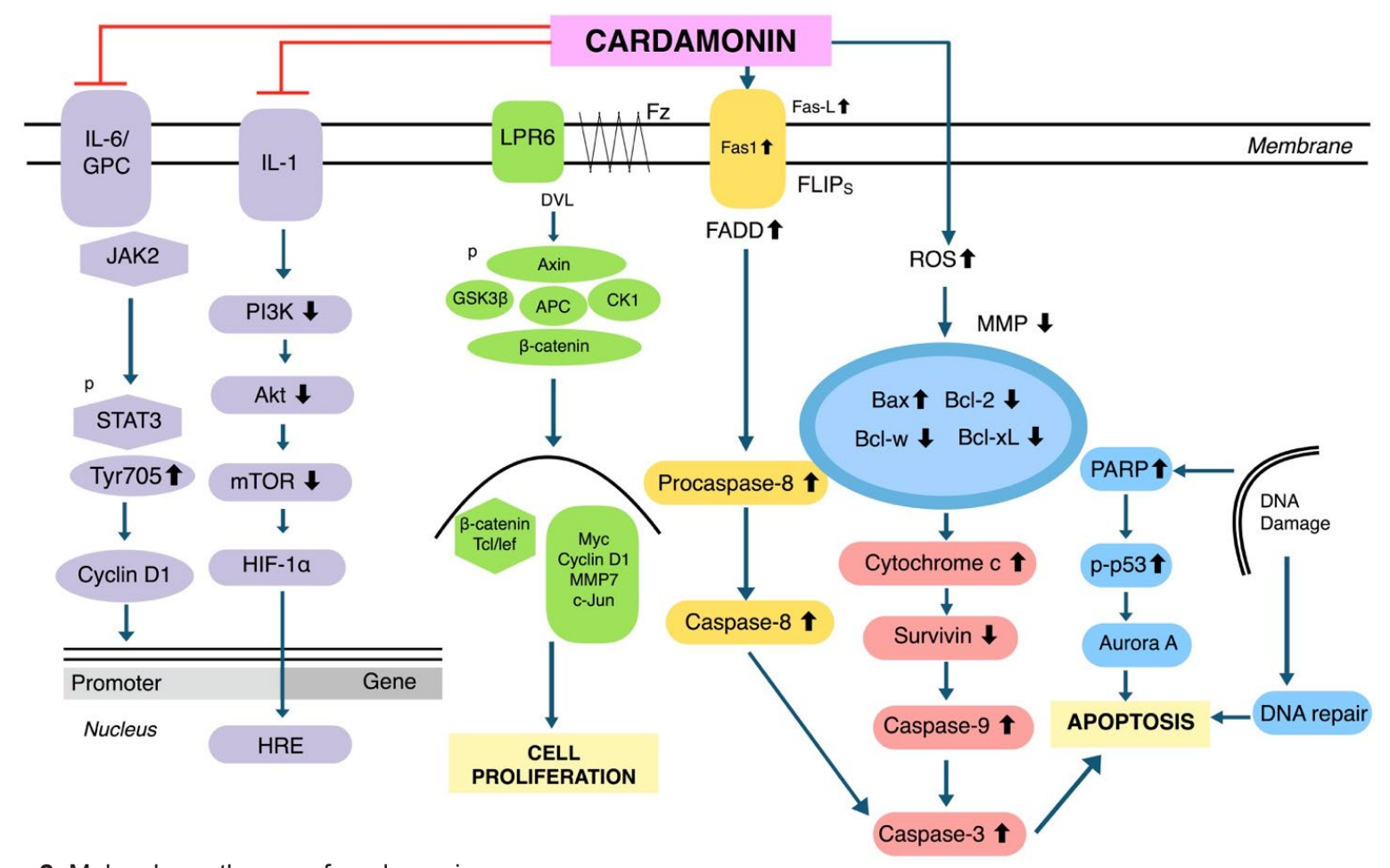

Figure 2. Molecular pathways of cardamonin 


\section{Breast carcinoma}

Breast cancer is the second-leading cause of cancer-related mortalities in women worldwide [31-34]. In 2019, approximately 42, 000 breast cancer mortalities occurred in the United States alone [35]. In a study by Kong et al. [17], the pretreatment of MDA-MB231 and MCF-7 cells with cardamonin resulted in the induction of G2/M cell cycle arrest, through the downregulation of cyclin D1, and apoptosis. Through the upregulation of c-Jun FOS-binding proteins-a family of protein kinases responsible for an apoptosis-FOXO3a translocation was enhanced, along with its downstream regulatory proteins: p21, p27, and Bim. Additionally, cardamonin increases the expression of activated caspase- 3 to induce cell death [17]. Furthermore, the Wnt/ $\beta$-catenin pathway was downregulated through the inhibition of phosphorylated glycogen synthase kinases (GSKs) through Akt [20]. Cardamonin has been shown to suppress the growth of breast cancer cell lines in vitro. A study conducted by Jin et al. [36], on MDA-MB-231 breast cancer cells highlighted the ability of cardamonin to mediate ROS-induced apoptosis by decreasing the expression of critical cell metabolic modulators, such as HIF-1a. The $\mathrm{IC}_{50}$ values of MDA-MB-231 are $52.885 \mu \mathrm{M}, 33.981 \mu \mathrm{M}$, and $33.981 \mu \mathrm{M}$ for $24 \mathrm{~h}, 48 \mathrm{~h}$, and $72 \mathrm{~h}$, respectively [36]. The natural flavone inhibited mRNA levels by suppressing mTOR/p70S6K levels. Also, mTOR regulates the invasion and motility of cancer cells. Through the retardation of these targets, cardamonin can suppress cell proliferation in various malignancies [36]. Moreover, Nrf2-dependent proteins were downregulated, which further increased ROS levels. Pretreatment with cardamonin inhibited glycolysis and increased OXPHOS signaling [36]. In another study, cardamonin suppressed the growth of drug-resistant breast CSCs and prevented the self-renewal of CSCs through the inhibition of NF- $\kappa B$ and STAT3 pathways. In CSCs, cardamonin has displayed promising effects when used in combination with chemotherapeutic agents through the downregulation of IL-6 and IL-8 pro-inflammatory factors [37]. Cardamonin has been reported to reduce the invasion and migration of triple-negative breast cancer cells (TNBC, BT-549 cells) via reversal of EMT by increasing the levels of E-cadherin [37-38]. Cardamonin also caused the downregulation of Snail, Slug, and Vimentin, crucial mesenchymal markers [37-39]. Through these mechanisms, cardamonin has been proven to have inhibitory effects against breast cancer cell lines.

\section{Cervical carcinoma}

Cervical cancer is deadly cancer occurring in women and has a considerably high mortality rate especially in low- and middle-class income groups, due to the lack of awareness and affordable treatment [40]. It is, therefore, imperative, that natural and inexpensive treatments are formulated for cervical cancer patients. Additionally, several cancers, such as cervical and breast cancers, are resistant to mTOR inhibitors. In a study, HeLa cervical cancer cells, which were resistant to high doses of mTOR-inhibitors have been treated with cardamonin. Cardamonin treatment was efficient enough to attenuate cell proliferation through reduced phosphorylation of mTOR and S6K1 in mTOR inhibitor-resistant HeLa cells [41].

\section{Colon carcinoma}

Colon cancer is the third most prevalent cancer in the United States in both men and women. The death rate of colon cancer has been noticed to be reduced over the last decade; however, it is still expected to cause around 55,000 deaths in 2020. The combination of cardamonin with other chemotherapeutic agents such as 5-FU was reported to reduce the growth of chemo-resistant HCT-116 colon cancer cells whiling inducing apoptosis [42]. The compound has been shown to activate caspase- 3 and caspase-9, increased expression of pro-apoptotic Bax, decreased expression of anti-apoptotic Bcl-2, and regulated c-Myc, octamer-binding transcription factor $4 \mathrm{k}$ (OCT4), Cyclin E, including cell cycle arrest [42]. Moreover, cardamonin downregulated testes-specific protease 50 and NF-kB p65 expression [42]. In another study, cardamonin inhibited $\beta$-catenin response transcription in SW480 colon cancer cells and induced G2/M cell cycle arrest. The compound decreased levels of $\beta$-catenin, on which catenin response transcription (CRT) is highly dependent, and inhibited cyclin D1 and c-Myc [43]. Furthermore, it inhibited $\beta$-catenin/TCF-4, a downstream protein of $\beta$-catenin. Through these mechanisms of action, cardamonin expressed its therapeutic potential on cells carrying mutations in the $A P C$ genes, without posing any threat on the levels of mRNA [43]. 


\section{Gastric cancer}

Being the fifth most commonly diagnosed cancer, and the third deadliest cancer globally, gastric cancer has a survival rate of less than 5\% [44-48]. Cardamonin has proven to be an effective treatment in AGS cells by inhibiting cell proliferation, migration, and induced apoptosis. Cardamonin downregulated the expression of anti-apoptotic Bcl-2 protein while upregulating Bax and caspase- 3 levels. Furthermore, cardamonin was reported to increase of p21, and decrease CDK1, cyclin B1, and CDC25c to block the AGS cells in the G0/G1 phase of the cell cycle [49]. Cardamonin also suppressed the expression of the EMT markers including Snail, Slug, and Vimentin, and increased E-cadherin expression levels. Another study emphasized the useful effect of cardamonin when used in combination with 5-FU. In this study, cardamonin was displayed to enhance the chemosensitivity of BCG-823 and BCG-823/5-FU cells through the inhibition of the Wnt/ $\beta$-catenin pathway [50]. This led to the mediation of TCF4 transcription and resulted in apoptosis and cell cycle arrest in vitro [50]. These two studies indicate that cardamonin exerts the anti-cancer effect either alone or in conjunction with other drugs.

\section{Glioblastoma}

Glioblastoma is a type of brain malignancy, which commonly occurs in adults and is extremely aggressive due to its ability to metastasize and resistance to chemotherapy [51]. Cardamonin was shown to sensitize the $\mathrm{CD} 133^{+}$GSCs in vitro. Cardamonin inhibited the expression of Bcl-2, Bcl-xL, and Mcl-1 proteins, and increased Bax levels, resulting in decreased proliferation and robust apoptosis. Levels of survivin and VEGF were also decreased through docking in nuclear STAT3 activation. When docked, these proteins have high binding energies of $-10.78 \mathrm{kcal} / \mathrm{moL}$, resulting in a highly energized exothermic process [52]. Therefore, the inhibition of STAT3 activation via cardamonin led to a decrease in the proliferative properties of CD133 ${ }^{+}$cells in glioblastoma.

\section{Leukemia}

Cardamonin has shown promising anti-leukemic activity against leukemia cells. A study conducted by Liao et al. [53], investigated the effect of cardamonin on WEHI-3 mice cells in vitro and found that the compound decreased cell viability and enhanced apoptosis through the mediation of numerous proteins. Firstly, ROS activity and the production of $\mathrm{Ca}^{2+}$ was increased, resulting in ROS-induced apoptosis. Mitochondrial membrane potential (MMP) was downregulated, while caspase-3, caspase-8, and caspase-9 were upregulated [53]. An increase in pro-apoptotic factors including cytochrome C, AIF, Bax, Endo G release, and caspase- 12 was observed, as well as a decrease in anti-apoptotic Bcl-2 with pretreatment with cardamonin [53]. Apoptotic cell death was induced through an increase in Fas, FaDD, and Fas-ligand expression. Furthermore, cardamonin treatment was associated with increased expression of Bax inhibitor motif-containing 4, ATG5, DDIT3, DDIT4, and BRCA1-associated ATM activator 1. This resulted in a change in the morphology of WEHI-3 cells, in turn, causing programmed cell death [53].

\section{Lung cancer}

Globally, lung cancer accounts for one-fourth of cancer-related deaths [54-59]. Cardamonin has provided promising anticancer efficacy against lung cancer in vitro. In non-small-cell lung cancer (NSCLC) A549 and H460 cells, cardamonin activated caspase-3, increased Bax levels, decreased Bcl-2 levels, thus inducing apoptosis [60]. Furthermore, the downregulation of cyclin D1/CDK4 levels resulted in the induction of cell cycle arrest in the G2/M phase. Moreover, treatment with cardamonin also reversed EMT transition and regulated several downstream factors including PI3K and mTOR signaling [60]. Through these mechanisms, the compound suppressed the ability of these NSCLC to invade and migrate. Several previous studies have established that cardamonin is highly associated with mTOR inhibition [60]. Similarly, in a second study, the chalcone generated a reduction in proliferative, invasionary, and migratory properties of LLC cells through the attenuation of Snail and other downstream targets including ribosomal S6K1 and the inhibition of NF$\kappa \mathrm{B}$ [61]. Additionally, levels of E-cadherin were upregulated and intracellular adhesion and separation of cancerous cells from tissues, i.e. the ability to metastasize, were decreased through the regulation of mTOR 
pathways [62]. Another study has utilized two analogs of cardamonin, DHC, and DHMC against A549 and $\mathrm{NCI}-\mathrm{H} 460$ lung cancer cells [62]. The activity of these analogs downregulated the activation of NF- $\mathrm{KB}$ and induced apoptosis [62]. In a final study, cardamonin was reported to attenuate cell proliferation and induce cell cycle arrest in A549 lung cancer cell lines. Cardamonin inhibited p70S6K and mTOR activation but did not affect the levels of FKBP12 and IL-2 [63]. Nevertheless, the expression of these proteins was decreased through binding with rapamycin [64]. Through these four studies, there is strong evidence that cardamonin can suppress the growth of lung cancer malignancies with experiments performed on in vitro cell lines.

\section{Melanoma}

Melanoma is the deadliest type of skin cancer and accounts for over three-fourths of skin cancer mortalities $[61,65]$. Several natural remedies, which involve using plant constituents, are being tested against melanomas. Melanomas can metastasize easily through lymph nodes and treatment options are relatively ineffective. Consequently, dietary chalcone was used against $\mathrm{A} 375$ malignant cell lines and $\mathrm{IC}_{50}$ values were $3.98 \mu \mathrm{M}$ for $48 \mathrm{~h}$ and $2.43 \mu \mathrm{M}$ for $96 \mathrm{~h}$, respectively. Further, no significant toxicity of cardamonin against normal human epidermal melanocytes was reported [65]. Cardamonin can induce apoptosis of A375 cells through an increase in caspase- 3 and PARP cleavage activity. These data displayed that cardamonin has a stronger cytotoxic effect on melanoma cells compared to healthy cells in vitro [65]. Another study showed that cardamonin reduced the cell viability in a concentration-dependent manner in melanoma M14 and A375 cell lines [61] by enhancing cell death through the upregulation of Bax, cleaved caspase-8, -9 , and PARP, and downregulation of Bcl-2 factors. Furthermore, cardamonin can inhibit the NF- $\kappa B$ pathway intrinsically and extrinsically as levels of p65 were decreased [61].

\section{Multiple myeloma}

Multiple myeloma is another type of blood cancer occurring in plasma cells [66-71]. The therapeutic potential of cardamonin was tested against multiple myeloma cell lines. Pretreatment with cardamonin increased caspase- 3 and PARP activation, and caused the suppression of numerous anti-apoptotic proteins, thus, inducing apoptosis and reducing cell viability in human myeloma cells [70-71]. Cardamonin also reduced the activation of the NF- $\mathrm{KB}$ pathway, through an increase in IKK and IkBA phosphorylation. Also, the levels of ICAM-1, COX-2, and VEFG were attenuated [70-71]. Moreover, cardamonin was found to suppress cell proliferation and induced apoptosis in human myeloma cells and exhibited several anti-myeloma effects, including reduced cell viability and blocking of specific proteins involved in the cell cycle, leading to eventual arrest [70-71].

\section{Ovarian cancer}

Ovarian cancer is the most common type of gynecological malignancy worldwide. The 5-year survival rate of ovarian cancer is between $20-47 \%$. Platinum-based chemotherapies are the best treatment against ovarian cancer in the clinics. Cardamonin has been associated with anti-proliferative effects against SKOV3 and A2780 ovarian cancer cells by inducing apoptosis, attenuating the levels of Bcl-2, survivin, and mTOR cascade. Additionally, cardamonin induced cell cycle arrest in the G2/M phase. Also, their study proved that the combined treatment of cardamonin along with cisplatin has a stronger and synergistic anti-cancer effect [72]. Another study, conducted on SKOV3 ovarian cancer cells, demonstrated the antiproliferative properties of cardamonin. The compound also enhanced autophagy or the removal of damaged cells by suppressing mTORC1 pathways and H2K expression. Cardamonin was reported to decrease the production of ATP and lactate along with upregulated microtubule-associated protein 1 LC3-II, and lysosome-associated membrane protein 1 upregulation [73].

\section{Prostate cancer}

The occurrence of prostate cancer is extremely high, affecting one in every nine men worldwide, with older men being more at risk [74-75]. Zhang et al. [74], have reported that cardamonin can efficiently block the STAT3 signaling cascade to repress the growth and viability of prostate cancer cells. Pascoal et al. [75], have 
demonstrated the effect of the isolated chalcone on PC-3 cell lines. This study showed that the cardamonin decreased the proliferation and viability of PC-3 cells via decreased expression of NF- $\mathrm{KB}$.

\section{Anti-tumor efficacy of the cardamonin in vivo using the murine model system}

Aside from in vitro studies, the effects of cardamonin have been further investigated in preclinical studies, particularly in murine models (Table 2). A study conducted by Jin et al. [36], has displayed that coadministration of cardamonin and 5-FU against MDA-MB-231 xenograft models caused decreased tumor growth with an increased cleaved caspase- 3 and Bax/Bcl-2 ratio. This study reported that the combination had minimal effect on the overall body weight of the mice. Cardamonin treatment has been found to attenuate the levels of HIF-1 $\alpha$ and LDHA and resulted in decreased tumor angiogenesis [36]. Interestingly, in another study in breast cancer, combined treatment of cardamonin along with other chemotherapeutic drugs was found to reduce the growth of CSCs and tumor growth. Cardamonin can reduce xenograft tumor growth in TNBCs at a dose of $5 \mathrm{mg} / \mathrm{kg}$ [37]. The 5-FU along with chalcone was noticed with the marked reduction of neoplasm growth in chemo-resistant gastric cancer BCG-823/5-FU cells in BALB/c xenograft nude mice, confirming in vitro findings [51]. An extensive study was carried out in vivo to test the ability of cardamonin against leukemia affected BALB/c mice. The mice were divided into four groups, including negative and positive controls; the groups were treated with $1 \mathrm{mg} / \mathrm{kg}$ and $5 \mathrm{mg} / \mathrm{kg}$ doses of the compound for two weeks. The results indicated that $\mathrm{CD} 3, \mathrm{CD} 11 \mathrm{~b}$, and Mac-3 were downregulated, however, CD19 proteins were upregulated [53]. Cardamonin also enhanced immune system capacity by increasing the phagocytic ability of macrophages in peripheral blood mononuclear cells, serving as a therapeutic agent for leukemia patients preclinically [53]. Furthermore, cardamonin reduced tumoral growth and induced apoptosis in NSCLC A549 and H460 lung cancer cells, by decreasing expression rates of Ki-67 and phosphorylated Akt and mTOR. Tumor growth and metastatic abilities were reduced by the PI3K/Akt/mTOR pathway [60,62]. Results from another in vivo lung cancer study conducted on LLC cells indicated that both lung cancer metastasis and tumoral growth were suppressed through the inhibition of $\mathrm{mTOR}$, as rapamycin prevented movement to distant nodes [60, 62].

Table 2. Anticancer effects of cardamonin in vivo

\begin{tabular}{|c|c|c|c|c|}
\hline Cancers & Cell line & Phenotypic effects & Mechanisms of action & References \\
\hline \multirow[t]{2}{*}{ Breast cancer } & MDA-MB-231 & $\begin{array}{l}\text { Inhibitory effects on tumor } \\
\text { angiogenesis }\end{array}$ & $\begin{array}{l}\downarrow \mathrm{Bcl}-2, \uparrow \text { Bax, } \uparrow \text { caspase-3, } \\
\downarrow \mathrm{HIF}-1 \mathrm{a}, \downarrow \text { LDHA }\end{array}$ & [36] \\
\hline & Drug-resistant CSC's & Inhibited tumor growth and volume & - & {$[37]$} \\
\hline Gastric cancer & BCG-823/5-FU & Reduced tumor growth & - & {$[50]$} \\
\hline Leukemia & BALB/c mice & - & $\downarrow \mathrm{CD} 3, \downarrow \mathrm{CD} 11 \mathrm{~b}, \downarrow$ Mac-3, $\uparrow \mathrm{CD} 19$ & [53] \\
\hline \multirow[t]{2}{*}{ Lung cancer } & NSCLC A549, H460 & $\begin{array}{l}\text { Reduced cell proliferation and } \\
\text { metastatic abilities }\end{array}$ & $\downarrow \mathrm{Ki}-67, \downarrow \mathrm{mTOR}, \downarrow$ Akt & {$[60]$} \\
\hline & LLC cells & $\begin{array}{l}\text { Suppressed lung metastasis and } \\
\text { tumoral growth }\end{array}$ & $\downarrow \mathrm{mTOR}$ & [62] \\
\hline
\end{tabular}

\section{Biosafety profiling of cardamonin}

Berning and colleagues have shown that cardamonin represses the growth of melanoma cells without affecting the normal cells [65]. Few studies describe the biosafety profile of cardamonin. Their studies showed that few data are available on its absorption, distribution, metabolism as well as excretion of the cardamonin [76-77]. Jaiswal et al. [78-79], have reported that cardamonin is less soluble as well as a high rate of permeability/penetration. Cardamonin has a moderate ability to binds with plasma proteins as well as its lower uptake in red blood cells. Cardamonin was displayed to be excreted from mice in the feces in the major amount whereas a small amount was present in urine. Cardamonin displayed anti-tumor potential but its limited bioavailability suppresses the effectiveness of cardamonin [78-79]. The bioavailability of cardamonin was reported to gender-biased in the experiments performed on rats. Therefore, more studies are required to improve the bioavailability in near future. 


\section{Conclusions and future perspective}

Cancer belongs to one of the greatest causes of mortality worldwide, responsible for 9.6 million deaths in 2018. Although there are numerous advancements in cancer research, methods of cancer diagnosis, development, and approval of the new drugs for treatment, still the scope for improvement to develop better drugs with less toxic and side effects are required. One of the approaches can be the screening of natural compounds for their anti-tumor activity as several clinical grades and FDA approved drugs were extracted from natural bioresources. Cardamonin has shown anti-tumor activity in preclinical studies by targeting numerous signaling pathways such as Wnt/ $\beta$-catenin, NF- $\mathrm{BB}$, and STAT3. Attenuation of these signaling pathways by cardamonin induces cell cycle arrest and cell death either alone or in combination with other chemotherapeutic agents. Interestingly, cardamonin enhances the antitumor activity in drug-resistant cells in several malignancies. Moreover, cardamonin showed promising anti-cancer efficacy in xenograft murine models against breast, gastric, lung, and leukemia. These data suggest that cardamonin may be used in combination with existing drugs in several human malignancies to provide a strong foundation for clinical trials in the near future, especially in murine models. Also, the focus of future research on cardamonin will be to check its anti-inflammatory activity and association with immune response. We are hopeful that future studies will provide a strong basis for its clinical trials to determining whether cardamonin possesses the same antineoplastic effects in humans and the doses at which the compound is effective.

\section{Abbreviations}

Akt: protein kinase B

ATG5: autophagy-related 5

Bax: Bcl-2 associated X protein

Bcl-2: B-cell lymphoma 2

CSC: cancer stem cell

DDIT3: DNA-damage inducible transcript 3

DHC: 4,4'-dihydroxylchalcone

DHMC: 4,4'-dihydroxy-2'-methoxychalcone

EMT: epithelial-mesenchymal transition

F0X03a: Forkhead box 03

GSC: glioblastoma stem cells

GSK: glycogen synthase kinases

HIF-1a: hypoxia-inducible factor-1a

$\mathrm{IC}_{50}$ : half-maximal inhibitory concentration

IL-6: interleukin 6

IL-8: interleukin 8

LC3-II: light chain 3-II

LLC: Lewis lung carcinoma

mTOR: mammalian target of rapamycin

NF-кB: nuclear factor kappa-light-chain enhancer

Nrf-2: NF-E2 related factor 2

NSCLC: non-small-cell lung cancer

OXPHOS: mitochondrial oxidative phosphorylation

PARP: poly(ADP-ribose) polymerase

ROS: reactive oxygen species

S6K1: S56 kinase 1 
STAT3: signal transducer and activator of transcription 3

TNBC: triple-negative breast cancer

VEGF: vascular endothelial growth factor

\section{Declarations}

\section{Author contributions}

MG, SR conducted conceptualization; SR, IN, ND, MG wrote original draft preparation; and SR, IN, ND, MG wrote, reviewed, and edited the manuscript. All the authors have read the manuscript and agreed to the published version of the manuscript.

\section{Conflicts of interest}

The authors declare that they have no conflict of interest.

\section{Ethical approval}

Not Applicable.

\section{Consent to participate}

Not Applicable.

\section{Consent to publication}

Not Applicable.

Availability of data and materials

Not Applicable.

\section{Funding}

This work was supported by the Department of Biotechnology (DBT), under its Ramalingaswami Fellowship number BT/RLF/Re-entry/24/2014 and Science and Engineering Research Board under its ECRA scheme (SERB File No. ECR/2016/001519) award to Dr. Manoj Garg. The sponsor(s) have no role in designing, analysis, interpretation, and writing.

\section{Copyright}

(C) The Author(s) 2020.

\section{References}

1. Bray F, Ferlay J, Soerjomataram I, Siegel RL, Torre LA, Jemal A. Global cancer statistics 2018: GLOBOCAN estimates of incidence and mortality worldwide for 36 cancers in 185 countries. CA Cancer J Clin. 2018;68:394-424.

2. Siegel RL, Miller KD, Jemal A. Cancer statistics, 2019. CA Cancer J Clin. 2019;69:7-34.

3. GBD 2015 Risk Factors Collaborators. Global, regional, and national comparative risk assessment of 79 behavioural, environmental and occupational, and metabolic risks or clusters of risks, 1990-2015: a systematic analysis for the Global Burden of Disease Study 2015. Lancet. 2016;388:1659-724.

4. Ferlay J, Soerjomataram I, Dikshit R, Eser S, Mathers C, Rebelo M, et al. Cancer incidence and mortality worldwide: sources, methods and major pattern in GLOBOCAN 2012. Int J Cancer. 2015;36:E359-86.

5. Plummer M, de Martel C, Vignat J, Ferlay J, Bray F, Franceschi S. Global burden of cancers attributable to infections in 2012: a synthetic analysis. Lancet Glob Health. 2016;4:e609-16.

6. Wong ALA, Hirpara JL, Pervaiz S, Eu JQ Sethi G, Goh BC. Do STAT3 inhibitors have potential in the future for cancer therapy? Expert Opin Investig Drugs. 2017;26:883-87. 
7. Blackadar CB. Historical review of the causes of cancer. World J Clin Oncol. 2016;7:54-86.

8. Kirtonia A, Gala K, Fernandes SG, Pandya G, Pandey AK, Sethi G, et al. Repurposing of drugs: an attractive pharmacological strategy for cancer therapeutics. Semin Cancer Biol. 2020;5:S1044-579X(20)30094-8.

9. Shanmugam MK, Warrier S, Kumar AP, Sethi G, Arfuso F. Potential role of natural compounds as antiangiogenic agents in cancer. Curr Vasc Pharmacol. 2017;15:503-19.

10. Ashrafizadeh M, Javanmardi S, Moradi-Ozarlou M, Mohammadinejad R, Farkhondeh T, Samarghandian $S$, et al. Natural products and phytochemical nanoformulations targeting mitochondria in oncotherapy: an updated review on resveratrol. Biosci Rep. 2020;40:BSR20200257.

11. Patra S, Mishra SR, Behera BP, Mahapatra KK, Panigrahi DP, Bhol CS, et al. Autophagy-modulating phytochemicals in cancer therapeutics: current evidences and future perspectives. Semin Cancer Biol. 2020;22:S1044-579X(20)30104-8.

12. Hanahan D, Weinberg RA. Hallmarks of cancer: the next generation. Cell. 2011;144:646-74.

13. O'Brien ME, Borthwick A, Rigg A, Leary A, Assersohn L, Last K, et al. Mortality within 30 days of chemotherapy: a clinical governance benchmarking issue for oncology patients. Br J Cancer. 2006;95:1632-36.

14. Naz I, Ramchandani S, Khan MR, Yang MH, Ahn KS. Anticancer potential of raddeanin A, a natural triterpenoid isolated from Anemone raddeana Regel. Molecules. 2020;25:1035.

15. Ramchandani S, Naz I, Lee JH, Khan MR, Ahn KS. An overview of the potential antineoplastic effects of casticin. Molecules. 2020;25:1287.

16. Prasannan R, Kalesh KA, Shanmugam MK, Nachiyappan A, Ramachandran L, Nguyen AH, et al. Key cell signaling pathways modulated by zerumbone: role in the prevention and treatment of cancer. Biochem Pharmacol. 2012;4:1268-76.

17. Kong W, Li C, Qi Q, Shen J, Chang K. Cardamonin induces G2/M arrest and apoptosis via activation of the JNK-FOX03a pathway in breast cancer cells. Cell Biol Int. 2019; [Epub ahead of print].

18. Nawaz J, Rasul A, Shah MA, Hussain G, Riaz A, Sarfraz I, et al. Cardamonin: a new player to fight cancer via multiple cancer signaling pathways. Life Sci. 2020;250:117591.

19. James S, Aparna JS, Paul AM, Lankadasari MB, Mohammed S, Binu VS, et al. Cardamonin inhibits colonic neoplasia through modulation of MicroRNA expression. Sci Rep. 2017;7:13945.

20. Shrivastava S, Jeengar MK, Thummuri D, Koval A, Katanaev VL, Marepally S, et al. Cardamonin, a chalcone, inhibits human triple negative breast cancer cell invasiveness by downregulation of Wnt/ $\beta$-catenin signaling cascades and reversal of epithelial-mesenchymal transition. Biofactors. 2017;43:152-69.

21. Kashyap D, Tuli HS, Yerer MB, Sharma A, Sak K, Srivastava S, etal. Natural product-based nanoformulations for cancer therapy: opportunities and challenges. Semin Cancer Biol. 2019; [Epub ahead of print].

22. Merarchi M, Sethi G, Shanmugam MK, Fan L, Arfuso F, Ahn KS. Role of natural products in modulating histone deacetylases in cancer. Molecules. 2019;24:1047.

23. Hardy SD, Shinde A, Wang WH, Wendt MK, Geahlen RL. Regulation of epithelial-mesenchymal transition and metastasis by TGF- $\beta$, P-bodies, and autophagy. Oncotarget. 2017;8:103302-14.

24. Tewari D, Nabavi SF, Nabavi SM, Sureda A, Farooqi AA, Atanasov AG, et al. Targeting activator protein 1 signaling pathway by bioactive natural agents: possible therapeutic strategy for cancer prevention and intervention. Pharmacol Res. 2018;128:366-75.

25. Yang SF, Weng CJ, Sethi G, Hu DN. Natural bioactives and phytochemicals serve in cancer treatment and prevention. Evid Based Complement Alternat Med. 2013;2013:698190.

26. Break MKB, Chiang M, Wiart C, Chin CF, Khoo ASB, Khoo TJ. Cytotoxic activity of Boesenbergia rotunda extracts against nasopharyngeal carcinoma cells (HK1). Cardamonin, a Boesenbergia rotunda constituent, inhibits growth and migration of HK1 cells by inducing caspase-dependent apoptosis and G2/M-phase arrest. Nutr Cancer. 2002;9:1-11. 
27. Yarla NS, Bishayee A, Sethi G, Reddanna P, Kalle AM, Dhananjaya BL, et al. Targeting arachidonic acid pathway by natural products for cancer prevention and therapy. Semin Cancer Biol. 2016;40-41:48-81.

28. Nie X, Chen H, Niu P, Zhu Y, Zhou J, Jiang L, et al. DAP1 negatively regulates autophagy induced by cardamonin in SKOV3 cells. Cell Bio Int. 2020;44:2192-201.

29. National Center for Biotechnology Information (2020). PubChem Compound Summary for CID 641785, Cardamonin. Accessed July 7, 2020 from https://pubchem.ncbi.nlm.nih.gov/compound/Cardamonin

30. Gonçalves LM, Valente IM, Rodrigues JA. An overview on cardamonin. J Med Food. 2014;17:633-40.

31. Wang C, Kar S, Lai X, Cai W, Arfuso F, Sethi G, et al. Triple negative breast cancer in Asia: an insider's view. Cancer Treat Rev. 2018;62:29-38.

32. Jia LY, Shanmugam MK, Sethi G, Bishayee A. Potential role of targeted therapies in the treatment of triplenegative breast cancer. Anticancer Drugs. 2016;27:147-55.

33. Kansara S, Pandey V, Lobie PE, Sethi G, Garg M, Pandey AK. Mechanistic involvement of long non-coding RNAs in oncotherapeutics resistance in triple-negative breast cancer. Cells. 2020;9:1511.

34. Liu L, Ahn KS, Shanmugam MK, Wang H, Shen H, Arfuso F, et al. Oleuropein induces apoptosis via abrogating NF- $\mathrm{KB}$ activation cascade in estrogen receptor-negative breast cancer cells. J Cell Biochem. 2019;120:4504-13.

35. Siegel RL, Miller KD, Jemal A. Cancer statistics, 2015. CA Cancer J Clin. 2015;65:5-29.

36. Jin J, Qiu S, Wang P, Liang X, Huang F, Wu H, et al. Cardamonin inhibits breast cancer growth by repressing HIF-1 $\alpha$-dependent metabolic reprogramming. J Exp Clin Cancer Res. 2019;38:377.

37. Jia D, Tan Y, Liu H, Ooi S, Li L, Wright K, et al. Cardamonin reduces chemotherapy-enriched breast cancer stem-like cells in vitro and in vivo. Oncotarget. 2016;7:771-85.

38. Shinde A, Hardy SD, Kim D, Akhand SS, Jolly MK, Wang WH, et al. Spleen tyrosine kinase-mediated autophagy is required for epithelial-mesenchymal plasticity and metastasis in breast cancer. Cancer Res. 2019;79:1831-43.

39. Libring S, Shinde A, Chanda MK, Nuru M, George H, Saleh AM, et al. The dynamic relationship of breast cancer cells and fibroblasts in fibronectin accumulation at primary and metastatic tumor sites. Cancers. 2020;12:1270.

40. Ningegowda R, Shivananju NS, Rajendran P, Basappa, Rangappa KS, Chinnathambi A, et al. A novel 4,6-disubstituted-1,2,4-triazolo-1,3,4-thiadiazole derivative inhibits tumor cell invasion and potentiates the apoptotic effect of TNF $\alpha$ by abrogating NF-кB activation cascade. Apoptosis. 2017;22:145-57.

41. Niu P, Li J, Chen H, Zhu Y, Zhou J, Shi D. Anti-proliferative effect of cardamonin on mTOR inhibitorresistant cancer cells. Mol Med Rep. 2020;21:1399-407.

42. Lu S, Lin C, Cheng X, Hua H, Xiang T, Huang Y, et al. Cardamonin reduces chemotherapy resistance of colon cancer cells via the TSP50/NF- $\kappa B$ pathway in vitro. Oncol Lett. 2018;15:9641-6.

43. Park S, Gwak J, Han SJ, Oh S. Cardamonin suppresses the proliferation of colon cancer cells by promoting $\beta$-catenin degradation. Biol Pharm Bull. 2013;36:1040-4.

44. Manu KA, Shanmugam MK, Ramachandran L, Li F, Siveen KS, Chinnathambi A, et al. Isorhamnetin augments the anti-tumor effect of capecitabine through the negative regulation of NF-KB signaling cascade in gastric cancer. Cancer Lett. 2015;363:28-36.

45. Manu KA, Shanmugam MK, Li F, Chen L, Siveen KS, Ahn KS, et al. Simvastatin sensitizes human gastric cancer xenograft in nude mice to capecitabine by suppressing nuclear factor-kappa B-regulated gene products. J Mol Med (Berl). 2014;92:267-76.

46. Manu KA, Shanmugam MK, Ramachandran L, Li F, Fong CW, Kumar AP, et al. First evidence that $\gamma$-tocotrienol inhibits the growth of human gastric cancer and chemosensitizes it to capecitabine in a xenograft mouse model through the modulation of NF-kB pathway. Clin Cancer Res. 2012;18:2220-9. 
47. Hwang ST, Kim C, Lee JH, Chinnathambi A, Alharbi SA, Shair OHM, et al. Cycloastragenol can negate constitutive STAT3 activation and promote paclitaxel-induced apoptosis in human gastric cancer cells. Phytomedicine. 2019;59:152907.

48. Xu Z, Chen L, Xiao Z, Zhu Y, Jiang H, Jin Y, et al. Potentiation of the anticancer effect of doxorubicinin drugresistant gastric cancer cells by tanshinone IIA. Phytomedicine. 2018;51:58-67.

49. Wang $\mathrm{Z}$, Tang $\mathrm{X}, \mathrm{Wu} \mathrm{X}$, Yang $\mathrm{M}$, Wang $\mathrm{W}$, Wang $\mathrm{L}$, et al. Cardamonin exerts anti-gastric cancer activity via inhibiting LncRNA-PVT1-STAT3 axis. Biosci Rep. 2019;39:BSR20190357.

50. Hou G, Yuan X, Li Y, Hou G, Liu X. Cardamonin, a natural chalcone, reduces 5-fluorouracil resistance of gastric cancer cells through targeting Wnt/ $\beta$-catenin signal pathway. Invest New Drugs. 2020;38:329-39.

51. Shabnam B, Padmavathi G, Banik K, Girisa S, Monisha J, Sethi G, et al. Sorcin a potential molecular target for cancer therapy. Transl Oncol. 2018;11:1379-89.

52. Wu N, Liu J, Zhao X, Yan Z, Jiang B, Wang L, et al. Cardamonin induces apoptosis by suppressing STAT3 signaling pathway in glioblastoma stem cells. Tumour Biol. 2015;36:9667-76.

53. Liao NC, Shih YL, Chou JS, Chen KW, Chen YL, Lee MH, et al. Cardamonin induces cell cycle arrest, apoptosis and alters apoptosis associated gene expression in WEHI-3 mouse leukemia cells. Am J Chin Med. 2019;47:635-56.

54. Wang L, Syn NL, Subhash VV, Any Y, Thuya WL, Cheow ESH, et al. Pan-HDAC inhibition by panobinostat mediates chemosensitization to carboplatin in non-small cell lung cancer via attenuation of EGFR signaling. Cancer Lett. 2018;417:152-60.

55. Struzik J, Szulc-Dąbrowska L. NF-кB signaling in targeting tumor cells by oncolytic viruses-therapeutic perspectives. Cancers (Basel). 2018;10:426.

56. Lee JH, Mohan CD, Basappa S, Rangappa S, Chinnathambi A, Alahmadi TA, et al. The IкB kinase inhibitor ACHP targets the STAT3 signaling pathway in human non-small cell lung carcinoma cells. Biomolecules. 2019;9:875.

57. Hayano T, Garg M, Yin D, Sudo M, Kawamata N, Shi S, et al. SOX7 is down-regulated in lung cancer. J Exp Clin Cancer Res. 2013;32:17.

58. Baek SH, Ko JH, Lee JH, Kim C, Lee H, Nam D, et al. Ginkgolic acid inhibits invasion and migration and TGF- $\beta$ induced EMT of lung cancer cells through PI3K/Akt/mTOR inactivation. J Cell Physiol. 2017;232:346-54.

59. Ong PS, Wang L, Chia DM, Seah JY, Kong LR, Thuya WL, et al. A novel combinatorial strategy using Seliciclib ${ }^{\circledR}$ and Belinostat ${ }^{\circledR}$ for eradication of non-small cell lung cancer via apoptosis induction and BID activation. Cancer Lett. 2016;381:49-57.

60. Zhou X, Zhou R, Li Q, Jie X, Hong J, Zong Y, et al. Cardamonin inhibits the proliferation and metastasis of non-small-cell lung cancer cells by suppressing the PI3K/Akt/mTOR pathway. Anticancer Drugs. 2019;30:241-50.

61. Yue Y, Liu L, Liu P, Li Y, Lu H, Li Y, et al. Cardamonin as a potential treatment for melanoma induces human melanoma cell apoptosis. Oncol Lett. 2020;19:1393-9.

62. He W, Jiang Y, Zhang X, Zhang Y, Ji H, Zhang N. Anticancer cardamonin analogs suppress the activation of NF-kappaB pathway in lung cancer cells. Mol Cell Biochem. 2014;389:25-33.

63. Uzunalli G, Dieterly AM, Kemet CM, Weng HY, Soepriatna AH, Goergen CJ, et al. Dynamic transition of the blood-brain barrier in the development of non-small cell lung cancer brain metastases. Oncotarget. 2019;10:6334-48.

64. Tang Y, Fang Q, Shi D, Niu P, Chen Y, Deng J. mTOR inhibition of cardamonin on antiproliferation of A549 cells is involved in a FKBP12 independent fashion. Life Sci. 2014;99:44-51.

65. Berning L, Scharf L, Aplak E, Stucki D, von Montfort C, Reichert AS, et al. In vitro selective cytotoxicity of the dietary chalcone cardamonin (CD) on melanoma compared to healthy cells is mediated by apoptosis. PLoS One. 2019;14:e0222267. 
66. Kim C, Lee JH, Ko JH, Chinnathambi A, Alharbi SA, Shair OHM, et al. Formononetin regulates multiple oncogenic signaling cascades and enhances sensitivity to bortezomib in a multiple myeloma mouse model. Biomolecules. 2019;9:262.

67. Kim C, Lee SG, Yang WM, Arfuso F, Um JY, Kumar AP, et al. Formononetin-induced oxidative stress abrogates the activation of STAT3/5 signaling axis and suppresses the tumor growth in multiple myeloma preclinical model. Cancer Lett. 2018;431:123-41.

68. Shanmugam MK, Ahn KS, Lee JH, Kannaiyan R, Mustafa N, Manu KA, et al. Celastrol attenuates the invasion and migration and augments the anticancer effects of bortezomib in a xenograft mouse model of multiple myeloma. Front Pharmacol. 2018;9:365.

69. Kim SM, Lee JH, Sethi G, Kim C, Baek SH, Nam D, et al. Bergamottin, a natural furanocoumarin obtained from grapefruit juice induces chemosensitization and apoptosis through the inhibition of STAT3 signaling pathway in tumor cells. Cancer Lett. 2014;354:153-63.

70. Wang J, Qiu R, Yuan L, Meng F, Tang Q. Analysis on the Alpinia katsumadai components of Zingiberaceae plants and their functions on myeloma resistance. Pak J Pharm Sci. 2015;28 Suppl 3:1065-8.

71. Qin Y, Sun CY, Lu FR, Shu XR, Yang D, Chen L, et al. Cardamonin exerts potent activity against multiple myeloma through blockade of NF-KB pathway in vitro. Leuk Res. 2012;36:514-20.

72. Niu P, Shi D, Zhang S, Zhu Y, Zhou J. Cardamonin enhances the anti-proliferative effect of cisplatin on ovarian cancer. Oncology Lett. 2018;15:3991-97.

73. Shi D, Zhao D, Niu P, Zhu Y, Zhou J, Chen H. Glycolysis inhibition via mTOR suppression is a key step in cardamonin-induced autophagy in SKOV3 cells. BMC Complement Altern Med. 2018;18:317.

74. Zhang J, Sikka S, Siveen KS, Lee JH, Um JY, Kumar AP, et al. Cardamonin represses proliferation, invasion, and causes apoptosis through the modulation of signal transducer and activator of transcription 3 pathway in prostate cancer. Apoptosis. 2017;22:158-68.

75. Pascoal AC, Ehrenfried CA, Lopez BG, de Araujo TM, Pascoal VD, Gilioli R, et al. Antiproliferative activity and induction of apoptosis in PC-3 cells by the chalcone cardamonin from Campomanesia adamantium (Myrtaceae) in a bioactivity-guided study. Molecules. 2014;19:1843-55.

76. Okoniewska K, Konieczny MT, Lemke K, Grabowski T. Pharmacokinetics studies of oxathio-heterocycle fused chalcones. Eur J Drug Metab Pharmacokinet. 2017;42:49-58.

77. Gutteridge CE, Thota DS, Curtis SM, Kozar MP, Li Q, Xie L, et al. In vitro biotransformation, in vivo efficacy and pharmacokinetics of antimalarial chalcones. Pharmacology. 2011;87:96-104.

78. Jaiswal S, Shukla M, Sharma A, Rangaraj N, Vaghasiya K, Malik MY, et al. Preclinical pharmacokinetics and ADME characterization of a novel anticancer chalcone, cardamonin. Drug Test Anal. 2016;9:1124-36.

79. Jaiswal S, Sharma A, Shukla M, Lal J. Gender-related pharmacokinetics and bioavailability of a novel anticancer chalcone, cardamonin, in rats determined by liquid chromatography tandem mass spectrometry. J Chromatogr B Analyt Technol Biomed Life Sci. 2015;986-987:23-30. 